\title{
A interdisciplinaridade na ação de projetar ambientes virtuais de aprendizagem: o caso NUTED/ UFRGS
}

Silvia Porto Meirelles Leite

Orientador: Profa. Dra. Patricia Alejandra Behar

Co-orientador: Profa. Dra. Maria Luiza Becker

Data de defesa: 29 de setembro de 2008

A presente tese investiga o fenômeno projetos interdisciplinares de Ambientes Virtuais de Aprendizagem (AVA's), destacando sua recorrência em diferentes contextos. Para tanto, realiza um estudo de caso sobre o engendramento da interdisciplinaridade na ação de projetar AVA's no Núcleo de Tecnologia Digital Aplicada à Educação (NUTED) da Universidade Federal do Rio Grande do Sul (UFRGS), no qual são desenvolvidos os projetos ROODA, PLANETA ROODA e ETC. Entendese que o debate a cerca desse tema contribui para uma reflexão sobre o desenvolvimento científico e tecnológico em informática na educação, bem como sua natureza interdisciplinar. Tal abordagem agrega uma perspectiva teórico-metodológica piagetiana, a qual orientou os questionamentos, a elocução conceitual e a coleta e as análises dos dados. Com isso, enfoca-se a construção de conhecimento a partir da interação entre sujeito (projetista) e objeto de estudo (AVA), entre sujeitos (projetistas) e entre os conhecimentos disciplinares, elucidando a interdependência entre as relações individuais, interindividuais e interdisciplinares. Também é abordado o jogo entre forma e conteúdo que caracteriza a ação de projetar e a interdisciplinaridade, de modo que os observáveis apontados e as coordenações realizadas pelos projetistas se configuram como os observáveis dessa tese. As três unidades de análise observadas nas fontes de evidência desse caso são: sistema de significações, valores coletivos e regras formais. A partir das relações entre as evidências coletadas e os pressupostos teórico-metodológicos, realizam-se coordenações que convergem para as categorias de análise, que são: relações interdisciplinares, criação de novidades e cooperação entre os projetistas.

Palavras-Chave: Interdisciplinaridade. Cooperação. Ambiente Virtual de Aprendizagem. Epistemologia Genética. Abstração Reflexionante. 